\title{
Measurement of Teacher Performance in Pematangsiantar City Middle School Through Teacher Certification, Motivation, and Job Satisfaction
}

\author{
Darwin Lie $^{1}$, Sherly $^{2}$, Efendi ${ }^{3}$, Edy Dharma ${ }^{4}$, Acai Sudirman ${ }^{5 *}$ \\ 1,2,3,4,5 Sultan Agung College of Economics, Indonesia \\ *E-mail:acaivenly@stiessultanagung.ac.id
}

\begin{abstract}
One of the indicators for the success of quality education in schools is to pay attention to and improve a teacher's performance. The urgency of a teacher's performance has implications for the effectiveness of the learning process in schools. The essence of this research is to determine the role of teacher certification, motivation, and job satisfaction in influencing teacher performance. This study uses a literature and field research design with a quantitative causality approach. Collect data in the field using observation methods and distributing questionnaires online from July to September 2020. The questionnaire was measured by several questions related to teacher certification, motivation, job satisfaction, and teacher performance. This study used a sample of 215 respondents to determine the sample size using the purposive sampling method. A partial least square is applied to examine the relationship between teacher performance, teacher certification, motivation, and job satisfaction. The results of this study indicate that of the three hypotheses developed, there is one hypothesis that is rejected, namely for the effect of the motivation variable on the teacher performance variable, the results do not have a significant effect. As for the variable teacher certification and job satisfaction, the results significantly influenced teacher performance. The results of this study indicate that of the three hypotheses developed, there is one hypothesis that is rejected, namely for the effect of the motivation variable on the teacher performance variable, the results do not have a significant effect. As for the variable teacher certification and job satisfaction, the results significantly influenced teacher performance. The results of this study indicate that of the three hypotheses developed there is one hypothesis that is rejected, namely for the effect of the motivation variable on the teacher performance variable, the results do not have a significant effect. As for the variable teacher certification and job satisfaction, the results significantly influenced teacher performance.
\end{abstract}

Keywords: Teacher Certification, Motivation, Job Satisfaction, Teacher Performance

\section{INTRODUCTION}

A teacher needs extensive support through qualified professional development in carrying out the status of his profession[9]. One method to improve the quality of teachers is through teacher certification to determine a teacher has the appropriate competence to teach [10]. Improving the professional competence of a teacher can be done by conducting a certification process. The urgency of certification as part of improving the quality process and educational outcomes [11]. The expected utility with the holding of the certification program is to raise the willingness of teachers to improve their quality as professionals [12]. The manifestation of a teacher's work is responsible for test scores and class observation scores and assesses students based on non-test results [13]. The urgency of a certified teacher is the ability to make observations to provide assessments to students while in the classroom environment [14]. Finding[15], conveyed that teachers who have certification tend to do work according to the standards set by the school. Teachers with non-standard certifications indicate that they emphasize several key dispositions above the level of emphasis used by teachers with standard certification [16].

In addition to teacher certification, another factor that can affect the level of teacher performance is motivation. An organizational leader will explore motivational problems when his subordinates have poor performance [17]. For performance management interventions, it is necessary to take concrete steps in considering the assessment problem related to motivation. This is a very important matter for organizations to detect the factors that motivate their employees to act with the optimal abilities [18]. One form of extrinsic motivation does show a worrying 
relationship pattern with a representative of teacher performance [19]. The essence of the motivation function will be seen when there is a change in the situation before and after being given a stimulus in a teacher's mind in the form of work motivation [20]. To do a job following organizational planning, we need strong encouragement from the principal to the teacher in motivation [21]. A strong drive will always motivate a teacher to do the work according to the plan [22]. Impulse will work effectively when someone recognizes the role of the organization well[23]. This statement is supported by research results[24], which conveys that if a job can be completed on time, it is due to the high work motivation [1]. On the other hand, research done [25], said that the increase in performance experienced by a person does not have a significant relationship with motivation. The implications of improving performance can be due to other factors that have a high comprehensive contribution to a person's performance [2].

Regarding job satisfaction in the context of education, the essence of the role of a teacher will be realized if job satisfaction and needs are met[26] and school performance largely depends on the teaching staff in it [27]. On the other hand, those faced with upsetting and unpleasant situations at work tend to behave less effectively [28]. Studies [29] said if the rise and fall of someone's performance is determined by their satisfaction level when carrying out a job. The implications of the level of satisfaction are representative of someone who likes a job will be seen when there is awareness from within to do the job as well as possible [30]. Research [31], concluded that the increase in teacher performance could occur due to the encouragement of the work spirit and the level of job satisfaction obtained [4]. Study results from [32] stated that the increase in performance experienced by a worker did not significantly affect the level of job satisfaction he obtained [5]. Following the results of research submitted by [33], with significant teacher certification findings from a person's motivation and research results [32], research on job satisfaction does not have a dominant contribution to improving performance [7].

\section{METHOD}

A quantitative approach to causality is used as a research method with a theoretical model approach assessed by PLS-SEM analysis in a two-stage process. First, the research data analyzed for validity and reliability using Cronbach's alpha testing, composite reliability, outer loading and average variance extracted [8]. Then, perform a Confirmatory Factor Analysis analysis to check the model's fit and the reliability of the model and discuss the hypothesis through the variancebased Structural Equation Model (SEM) [34].
Determination of the number of samples using nonprobability sampling with purposive sampling technique. According to [34], the number of samples can be determined from 10 times the number of indicators used in a single construct. This study uses 32 indicators from the existing constructs, so the number of samples obtained is 320 . The instrument used for this study used an online questionnaire using a Likert scale, namely (1) stating "strongly disagree to" (5) "strongly agree". The measurement of the dependent and independent variables uses previous references relevant to the research topic and research variables. The measurement of the dependent variable, namely the teacher's performance is measured using[35]which consists of 14 indicators. Then forThe first independent variable, namely teacher certification, was measured using previous research [36]; [9] which consists of 10 indicators [3]. The second independent, namely motivation is measured using previous research penelitian [37]; For more details, framework The thoughts of this research can be explained in Figure 1 below:

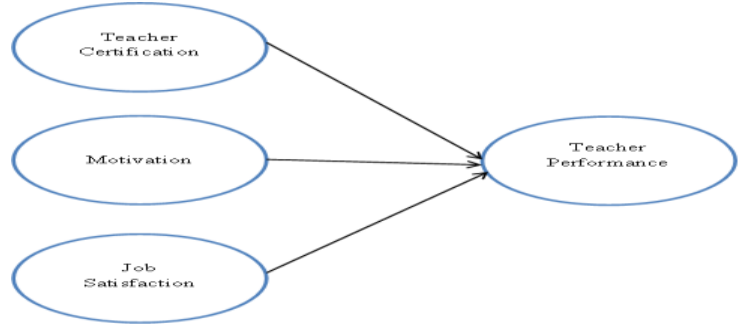

Picture 1. Research Framework Model

\section{RESULT}

The distribution of the questionnaires was carried out online using the google form media and distributed via whatsapp and telegram applications to private junior high school teachers in Pematangsiantar City [6]. Based on the recapitulation of the answers of respondents who filled out the online questionnaire, the data obtained were 320 respondents, but only 215 respondents filled in valid data. Therefore, the general characteristics of respondents in this study will clearly be described in table 1 below:

Table 1. General Profile of Respondents

\begin{tabular}{|c|c|c|c|}
\hline Category & Details & amount & Percentage \\
\hline \multirow{3}{*}{ Gender } & Men & 92 & $42.79 \%$ \\
& Woman & 123 & $57.21 \%$ \\
\hline \multirow{6}{*}{ Age } & 20-29 years old & 38 & $17.67 \%$ \\
& 30-39 years old & 95 & $44.19 \%$ \\
& 40-49 years old & 53 & $24.65 \%$ \\
& 50-59 years old & 29 & $13.49 \%$ \\
& 20-29 years old & 38 & $17.67 \%$ \\
\hline
\end{tabular}




\begin{tabular}{|c|c|c|c|}
\hline & high school & 7 & $3.26 \%$ \\
Level of & D1 to D3 & 54 & $25.12 \%$ \\
education & Bachelor & 133 & $61.86 \%$ \\
& Master & 21 & $9.76 \%$ \\
\hline & $<1$ Year & 12 & $5.58 \%$ \\
Years of & 1-5 Years & 16 & $7.44 \%$ \\
service & 6-10 Years & 44 & $20.47 \%$ \\
& $>10$ Years & 143 & $66.51 \%$ \\
\hline
\end{tabular}

Source: data processing results (2020)

\subsection{Outler Model Measurement}

The data obtained from the research questionnaire were processed using the SmartPLS version 3.2.9 application with management guidelines from [39]. In the measurement of the outer model, the tests carried out are validity tests and reliability tests. The loading factor and AVE determine convergent validity testing with the condition that the loading factor is above 0.7 and the AVE value is 0. 5[40]. Testing the reliability of the model according to [40]seen from the value of cronbanch's alpha and composite reliability (CR) which has a value greater than 0.7. In the following, an explanation of the measurement of the model's outlet is presented using table 2 below:

Table 2. Outler Model Measurement Results

\begin{tabular}{|l|c|c|c|c|}
\hline Construct/item & $\begin{array}{c}\text { Outler } \\
\text { Loadings }\end{array}$ & $\begin{array}{c}\text { Cronbach' } \\
\text { alpha }\end{array}$ & CR & AVE \\
\hline $\begin{array}{l}\text { Teacher } \\
\text { Certification }\end{array}$ & & $\mathbf{0 . 9 7 8}$ & $\mathbf{0 . 9 8 0}$ & $\mathbf{0 . 8 3 3}$ \\
\hline SG1 & 0.935 & & & \\
\hline SG2 & 0.950 & & & \\
\hline SG3 & 0.931 & & & \\
\hline SG4 & 0.901 & & & \\
\hline SG5 & 0.882 & & & \\
\hline SG6 & 0.878 & & & \\
\hline SG7 & 0.908 & & & \\
\hline SG8 & 0.891 & & & \\
\hline SG9 & 0.911 & & & \\
\hline SG10 & 0.939 & & & \\
\hline Motivation & & $\mathbf{0 . 9 2 2}$ & $\mathbf{0 . 9 4 9}$ & $\mathbf{0 . 8 6 2}$ \\
\hline MO1 & 0.929 & & & \\
\hline MO2 & 0.947 & & & \\
\hline MO3 & 0.909 & & & \\
\hline Job satisfaction & & $\mathbf{0 . 9 0 3}$ & $\mathbf{0 . 9 2 9}$ & $\mathbf{0 . 7 2 4}$ \\
\hline KK1 & 0.912 & & & \\
\hline KK2 & 0.849 & & & \\
\hline KK3 & 0.921 & & & \\
\hline KK4 & 0.785 & & & \\
\hline KK5 & 0.776 & & & \\
\hline Teacher & & $\mathbf{0 . 9 5 8}$ & $\mathbf{0 . 9 6 2}$ & $\mathbf{0 . 6 4 4}$ \\
\hline Performance & & & & \\
\hline KG1 & 0.796 & & & \\
\hline KG2 & 0.892 & & & \\
\hline KG3 & 0.789 & & & \\
\hline KG4 & 0.812 & & & \\
\hline KG5 & & & & \\
\hline & & & & \\
\hline
\end{tabular}

\begin{tabular}{|l|l|l|l|l|}
\hline KG6 & 0.732 & & & \\
\hline KG7 & 0.828 & & & \\
\hline KG8 & 0.843 & & & \\
\hline KG9 & 0.754 & & & \\
\hline KG10 & 0.870 & & & \\
\hline KG11 & 0.775 & & & \\
\hline KG12 & 0.752 & & & \\
\hline KG13 & 0.848 & & & \\
\hline KG14 & 0.770 & & & \\
\hline
\end{tabular}

Source: data processing results (2020)

In the validity test test presented in table 3 above, the value of each loading factor and AVE on the indicator variable teacher certification, motivation, job satisfaction and teacher performance is above 0.7 for the loading factor and above 0.5 for AVE.

\subsection{Inner Model Measurement}

The value of $\mathrm{R}$-square is a value that shows the ability of exogenous variables to build endogenous variables. According to[41] there are three categories of $\mathrm{R}$-square values, if the $\mathrm{R}$-square value is 0.19 the relationship between exogenous variables forming endogenous variables is weak, if it is 0.33 it means the relationship is moderate and if the value is 0.67 it means that the relationship is strong. While [42] states that if the $\mathrm{R}$-square value is more than 0.67 , the relationship between endogenous and exogenous is very strong.

Table 3. Calculation results of the R-Square nilai value

\begin{tabular}{|c|c|c|}
\hline \multicolumn{3}{|c|}{ value } \\
\hline Information & $R$ Square & $R$ Square Adjusted \\
\hline Teacher Performance & 0.307 & 0.297 \\
\hline
\end{tabular}

Source: data processing results (2020)

Judging from the R-square value of the endogenous variable, namely teacher performance, it was obtained a value of 0.307 , which means that the overall ability of the exogenous variable to explain the endogenous variable is moderate. Furthermore, to prove the hypothesis testing, a significance test was used to determine the relationship between exogenous variables and endogenous variables. The significant criterion is seen from the $\mathrm{p}$-value. The following presents the results of the hypothesis test which are explained in Figure 2 and Table 4 below:

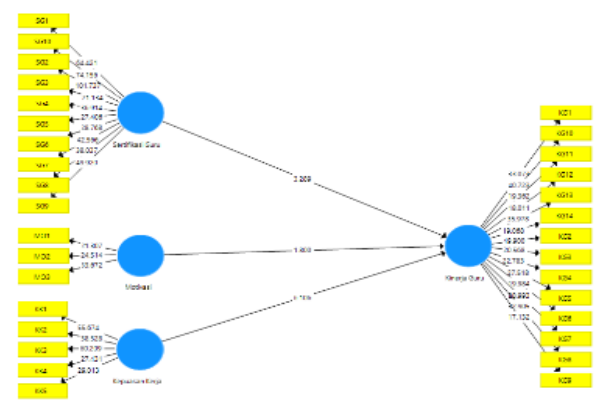

Figure2. Inner Model Display 
Table 4. Path Coefficients . Test Results

\begin{tabular}{|l|c|c|c|c|}
\hline $\begin{array}{c}\text { Path Between } \\
\text { Variables }\end{array}$ & $\begin{array}{c}\text { Coefficie } \\
\text { nt }\end{array}$ & tcount & P-Value & Conclusion \\
\hline $\begin{array}{l}\text { Teacher } \\
\text { certification } \\
\begin{array}{l}\text { > Teacher } \\
\text { performance }\end{array}\end{array}$ & 0.214 & 3.289 & $\mathbf{0 . 0 0 1}$ & Be accepted \\
\hline $\begin{array}{l}\text { Motivation } \\
\text { > Teacher } \\
\text { performance }\end{array}$ & 0.116 & 1,800 & $\mathbf{0 . 0 7 2}$ & Rejected \\
\hline $\begin{array}{l}\text { Job } \\
\text { Satisfaction } \\
\text { > Teacher } \\
\text { performance }\end{array}$ & 0.393 & 6.106 & $\mathbf{0 . 0 0 0}$ & Be accepted \\
\hline
\end{tabular}

Source: data processing results (2020)

Furthermore, the influence of job satisfaction on teacher performance variables also has a significant influence.

\section{DISCUSSION}

The results of this research have similarities with the findings [33] and [43], concludes that an increase in teacher performance can be achieved because every certified teacher will try to optimize his performance based on the assessment standards of the certification process. In addition, research results [44] show that teacher performance's effectiveness has significant relevance to the quality of certified teachers. Finding [45], also stated that there is a relationship between a teacher's performance and teacher certification so that the findings support the findings of this study.

The results of this study have similarities with the results of research conducted [46], whose findings state that motivation does not have a significant effect on the increase or decrease in performance. This situation can occur because someone who has high motivation in general will be oriented to job satisfactionwhile [47]. Representatives of optimal performance results are driven by the desire to work and the need for the work itself and not solely because of the motivation given by the leader [48]. The results of this study contradict the research conducted by [49]; [50] and [51], who said an increase in teacher performance could occur due to a strong motivational drive from a teacher. If the motivation given by the leader is in the form of positive encouragement, then the employees will directly influence the behavior of workers to do work optimally [52].

The results of this study have similarities with the results of research conducted by [53]; [54]; [55], which states that job satisfaction has a significant contribution to improving the performance of a teacher. When someone has job satisfaction and a willingness to commit to the job given to him, the expected implication is increased performance [56]. However, the results of this study contradict the research conducted by [57], which states that job satisfaction obtained by a worker does not significantly impact changes in performance. The same statement was also conveyed from research [58], whose findings conclude that changes in performance experienced by a person during the process of doing work, are not driven by the job satisfaction they get, but other factors encourage it such as motivation and the environment in which they work. work.

\section{CONCLUSION}

Testing the teacher certification variable indicates that the teacher certification factor has a positive and significant effect on teacher performance. The results of testing the motivation variableproves that motivation has a positive and insignificant effect on teacher performance. Job satisfaction variable test resultsproves that job satisfaction has a positive and significant impact on teacher performance. Judging from the R-square value of the endogenous variable, it can be interpreted that there is a moderate relationship between the variables of teacher certification, motivation, job satisfaction, and teacher performance.

\section{AUTHORS' CONTRIBUTIONS}

Darwin Lie As the first writer to carry out research activities, Sherly, Efendi and Edy Dharma as the second, third and fourth writers who have compiled articles from beginning to end, Acai Sudirman as corresponding writers who have edited the manuscript and carried out the review process.

\section{ACKNOWLEDGMENTS}

The author would like to thank the Sultan Agung College Foundation which has permitted to carry out this research and all school principals and middle school teachers in Pematagsiantar City by contributing to the success of this research.

\section{REFERENCES}

[1] AM Elbaz, GM Agag, and NA Alkathiri, "How Ability, Motivation And Opportunity Influence Travel Agents Performance: The Moderating Role Of Absorptive Capacity," J. Knowl. Manag., vol. 21, no. 2, pp. 275-294, 2017.

[2] E. Juniarti, N. Ahyani, and A. Ardiansyah, "The Influence of Principal Leadership and Teacher Discipline on Teacher Performance," J. Educ. res., vol. 1, no. 3, pp. 193-199, 2020 doi:10,47467/reslaj.v1i2.108.

[3] D. Lie, S. Sherly, E. Dharma, and A. Sudirman, "The Impact of Work Discipline and Work Ethic on the Teacher Performance of Sultan Agung Pematangsiantar Private Middle School Teachers FY 2018/2019," Int. J. Bus. Stud., vol. 3, no. 3, pp. 125- 
135, 2019, doi:10.32924/ijbs.v3i3.83.

[4] Sutrisno, "The Influence of Motivation and Work Discipline on Teacher Performance at Smk Sasmita Jaya - South Tangerang," J. Eco. ef., vol. 1, no. 3, pp. 183-195, 2019.

[5] A. Novitasari, A. Wahyudin, and R. Setiyani, "The Influence of Principal Leadership, Work Environment, Education, And Training on Teacher Performance," econ. Educ. anal. J., vol. 1, no. 2, pp. $1-6,2012$.

[6] FNK Siregar and P. Thomas, "The Influence of Work Discipline and Work Climate on the Performance of Economics/Accounting Teachers in State Senior High Schools in Wonosobo Regency," econ. Educ. anal. J., vol. 2, no. 3, pp. 1-8, 2014, [Online]. Available: http://journal.unnes.ac.id/sju/index.php/eeaj.

[7] HA Sobandi, "The Influence of Teacher Competence on Teaching Performance of Vocational High School Teachers in the Field of Business and Management Expertise in the City of Bandung," Managerial, vol. 9, no. 17, pp. 25-34, 2010.

[8] KT Utari and R. Rasto, "The Effect of Work Discipline on Teacher Performance," J. Educator. manaj. office, vol. 4, no. 2, pp. 246-253, 2019, doi:10.17509/jpm.v4i2.18019.

[9] MN Kobakhidze, Teacher Certification Examinations In Georgia: Outcomes And Policy Implications, vol. 19. Emerald Group Publishing Limited, 2013.

[10] PN Kusumawardhani, "Does Teacher Certification Program Lead To Better Quality Teachers? Evidence From Indonesia,"Educ. econ., vol. 25, no. 6, pp. 590618, 2017, doi:10.1080/09645292.2017.1329405.

[11] A. Sugianto, "The Effect of Certification on Teacher Performance in Arjasa District, Kangean Islands," econ. Educ. J., vol. 1, no. 1, pp. 10-20, 2019, doi:10.33503/ecoducation.v1i1.375.

[12] L. Mimbar, Izrawati, and E. Kartini, "Impact of Teacher Certification and Work Motivation on Teacher Performance in MTs. West Lombok Kuripan Model Country,"Valid J. Ilm., vol. 15, no. 2, pp. 136150, 2018.

[13] BA Jacob, JE Rockoff, ES Taylor, B. Lindy, and R. Rosen, "Teacher Applicant Hiring And Teacher Performance: Evidence From DC Public Schools," $J$. Public Eco., vol. 166, pp. 81-97, 2018, doi:10.1016/j.jpubeco.2018.08.011.

[14] D. Blazar and MA Kraft, "Teacher and Teaching Effects on Students' Attitudes and Behaviors," Educ. Eval. Policy Anal., vol. 39, no. 1, pp. 146-170, 2017, doi: 10.3102/0162373716670260.

[15] HR Milner and JC Laughter, "But Good Intentions are Not Enough: Preparing Teachers to Center Race and Poverty," Urban Rev., vol. 47, no. 2, pp. 341363, 2015, doi:10.1007/s11256-014-0295-4.

[16] KA Anderson, "A National Study of the Differential Impact of Novice Teacher Certification on Teacher Traits and Race-Based Mathematics Achievement," J. Teach. Educ., vol. 71, no. 2, pp. 247-260, 2019, doi:10.1177/0022487119849564.

[17] F. etin and D. Aşkun, "The Effect Of Occupational Self-Efficacy On Work Performance Through Intrinsic Work Motivation," Manag. res. Rev., vol. 41, no. 2, pp. 186-201, 2018, doi:10.1108/MRR-032017-0062.

[18] K. Pang and CS Lu, "Organizational Motivation, Employee Job Satisfaction And Organizational Performance: An Empirical Study Of Container
Shipping Companies In Taiwan," Marit. Buses. Rev. vol. 3, no. 1, pp. 36-52, 2018, doi:10.1108/MABR03-2018-0007.

[19] TH Bailey and LJ Phillips, "The Influence Of Motivation And Adaptation On Students' Subjective Well-Being, Meaning In Life And Academic Performance," High. Educ. res. Dev., vol. 35, no. 2, pp. 201-216,

2015 , doi:10.1080/07294360.2015.1087474.

[20] Sugito, Y. Suyitno, and Kuntoro, "The Effect of Working Period and Work Motivation on the Performance of Elementary School Teachers in Samudra and Samudra Kulon Villages," J. Din. Educator. Basic, vol. 11, no. 1, pp. 1-18, 2019.

[21] H. Tohidi and MM Jabbari, "The Effects of Motivation in Education," Procedia - Soc. Behav science., vol. 31, pp. 820-824, 2012, doi:10.1016/j.sbspro.2011.12.148.

[22] S. Shaheen, N. Perveen, Noshaba, and SK Malikz, "Motivational Techniques for Effective Learning: A Meta Analysis," Educ. Technol., vol. 64, pp. 1917019176, 2013.

[23] M. Rita, O. Randa Payangan, Y. Rante, R. Tuhumena, and A. Erari, "Moderating Effect Of Organizational Citizenship Behavior On The Effect Of Organizational Commitment, Transformational Leadership And Work Motivation On Employee Performance," int. J. Law Manag., vol. 60, no. 4, pp. 953-964, 2018, doi:10.1108/IJLMA-03-2017-0026.

[24] F. Gokce, "Assessment of Teacher Motivation," Sch. Leadersh. Manag., vol. 30, no. 5, pp. 487-499, 2010, doi:10.1080/1632434.2010.525228.

[25] S. Siahaan and S. Bahri, "The Influence of Placement, Motivation, and Work Environment on Employee Performance," Maneggio J. Ilm. Master of Management., vol. 2, no. 1, pp. 16-30, 2019, doi:10.30596/maneggio.v2i1.3402.

[26] A. Saiti and Y. Papadopoulos, "School Teachers' Job Satisfaction And Personal Characteristics: A Quantitative Research Study In Greece," int. J. Educ. Manag., vol. 29, no. 1, pp. 73-97, 2015, doi:10.1108/IJEM-05-2013-0081.

[27] GV Caprara, C. Barbaranelli, P. Steca, and PS Malone, "Teachers' Self-Efficacy Beliefs As Determinants Of Job Satisfaction And Students' Academic Achievement: A Study At The School Level," J. Sch. Psychol., vol. 44, no. 6, pp. 473-490, 2006, doi:10.1016/j.jsp.2006.09.001.

[28] J. Kwong, H. Wang, and RA Clifton, "Rethinking Our Assumptions About Teachers' Job Satisfaction In China And The West," Aust. J. Educ., vol. 54, no. 2, pp. 115-132, 2010

[29] S. Siengthai and P. Pila-Ngarm, "The Interaction Effect Of Job Redesign And Job Satisfaction On Employee Performance," J. Evidence-based HR, vol. 4, no. 2, pp. 162-180, 2016, doi:10.1108/EBHRM01-2015-0001.

[30] D. Armelsa and T. Mutiah, "The Influence of Leadership and Job Satisfaction on Teacher Performance at State Junior High Schools in Setu Subdistrict, Bekasi Regency," Horizon-Journal of Hum., vol. 19, no. 1, pp. 95-99, 2019.

[31] R. Ahmadiansah, "The Influence of Work Motivation and Job Satisfaction on the Performance of Vocational High School Teachers" Muhammadiyah Salatiga," Inject Interdiscip. J. Commun., vol. 1, no. 2, pp. 223-236, 2016, [Online]. Available: 
http://library1.nida.ac.th/termpaper6/sd/2554/19755.p df.

[32] I. Syahputra and J. Jufrizen, "The Effect of Training, Promotion, and Job Satisfaction on Employee Performance," Maneggio J. Ilm. Master of Management., vol. 2, no. 1, pp. 104-116, 2019, doi:10.30596/maneggio.v2i1.3364.

[33] SD Lestari, FM Leon, S. Widyastuti, NA Brabo, and AHPK Putra, "Antecedents and Consequences of Innovation and Business Strategy on Performance and Competitive Advantage of SMEs," J. Asian Finance. econ. Buses., vol. 7, no. 6, pp. 365-378, 2020, doi:10.13106/JAFEB.2020.VOL7.NO6.365.

[34] JF Hair, Multivariate Data Analysis 7th Edition. New Jersey: Pearson Prentice Hall, 2014.

[35] National PMP, Minister of National Education Regulation number 16 of 2007 concerning Academic Qualification Standards and Teacher Competence. 2007.

[36] TW Adi, N. Prambudiarto, and E. Hidyantari, "The Influence of Teacher Certification and Teacher Commitment to Teacher Performance," J. Econ. sustain. Dev., vol. 2, no. 1, pp. 25-34, 2017.

[37] BR Werang, O. Irianto, and HP Asmaningrum, "The Influence of Motivation and Work Spirit on the Performance of Elementary School Teachers in Mindiptana District, Papua," Musamus J Prim. Educ., vol. 1, no. 2, pp. 93-103, 2019, doi:10.35724/musjpe.v1i2.1467.

[38] R. Bogler and AE Nir, "The Importance Of Teachers' Perceived Organizational Support To Job Satisfaction. What's Empowerment Got To Do With It?"J. Educ. Adm., vol. 50, no. 3, pp. 287-306, 2012.

[39] A. Juliandi, "Structural Equation Model Based Partial Least Square (SEM-PLS): Using SmartPLS," 2018.

[40] JF Hair, Multivariate Data Analysis, 7th Edition. New Jersey: Pearson Prentice Hall, 2014.

[41] WW Chin, RA Peterson, and SP Brown, "Structural Equation Modeling In Marketing : Some Practical Reminders Structural Equation Modeling In Marketing : Some Practical Reminders," J. Mark. Theory Practice. ISSN, vol. 16, no. 4, pp. 287-298, 2008, doi:10.2753/MTP1069-6679160402.

[42] J. Sarwono, Making Thesis, Thesis and Dissertation with Partial Least Square SEM (PLS - SEM). Yogyakarta: Andi Offset, 2016.

[43] H. Hasmiah, "Impact of Certification on Improving the Quality of Teaching Teachers at the State Elementary School Complex IKIP Makassar City," JEKPEND J. Ekon. and Educator., vol. 3, no. 1, pp. 37-43, 2020, doi:10.26858/jekpend.v3i1.12003.

[44] R. Lin, J. Xie, Y.-C. Jeng, and S. Huang, "The relationship between teacher quality and teaching effectiveness perceived by students from industrial vocational high schools,"Asian J. Arts Sci., vol. 1, no. 2, pp. 167-187, 2010.

[45] F. Nugroho and RI Yudha, "The Influence of Teacher Certification on Teacher Performance in Economics Subjects in State High Schools in Kota Baru District, Jambi City," science. Journals Econ. Educ., vol. 2, no. 1, pp. 84-95, 2018.

[46] H. Murti and VA Srimulyani, "The Influence of Motivation on Employee Performance with Mediating Variables of Job Satisfaction at City Water Supply Madiun," JRMA J. Ris. manaj. and Accounts., vol. 1, no. 1, pp. 10-17, 2013.

DK Gultom, "The Influence of Corporate
Organizational Culture and Motivation on Employee Performance At Pt. State Gas Company (Persero) Tbk Medan,"J. Manaj. and Business, vol. 14, no. 2, pp. 176-184, 2014, [Online]. Available:

[48] I. Marjaya and F. Pasaribu, "The Influence of Leadership, Motivation, and Training on Employee Performance," Maneggio J. Ilm. Master of Management., vol. 2, no. 1, pp. 129-147, 2019, doi:10.30596/maneggio.v2i1.3650.

[49] Firmawati, Yusrizal, and N. Usman, "The Influence of Principal Leadership and Work Motivation on Teacher Performance," J. Masters Adm. Educator., vol. 5, no. 3, pp. 167-171, 2017, doi: $10.26877 / \mathrm{jmp} . v 5 \mathrm{i} 3.1984$.

[50] AD Astuti, "The influence of motivation and work discipline on the performance of elementary school teachers in Cilacap Regency," J. Management Accountability. Educator., vol. 5, no. 2, p. 150, 2017, doi:10.21831/amp.v5i2.13931.

[51] R. Putra, Nyoto, Sayono, and E. Wulandari, "The Influence of Motivation, Training, Organizational Culture, and Organizational Commitment on Job Satisfaction and Teacher Performance at SMK Negeri Pekanbaru City," J. Ilm. manaj., vol. 7, no. 3, pp. 328-343, 2019.

[52] Y. Syamra, "The Effect of Financial Compensation and Teacher Work Motivation on Teacher Performance at State Vocational High Schools in Padang City," econ. J. Econ. econ. Educ., vol. 4, no. 2, pp. 258-268, 2016, doi:10.22202/economica.v4i2.628.

[53] H. Kurniadi, "The Effect of Job Satisfaction and Work Discipline on Performance With Motivation as an Intervening Variable (Empirical Study on Teachers of SMK Negeri 2 Purworejo)," J. Eco. and Tech. information., vol. 1, no. 1, pp. 51-61, 2013.

[54] EE Pratiwi and L. Idawati, "The Influence of Servant Leadership, Job Satisfaction, And Intrinsic Motivation on Teacher Performance at Lentera Harapan Sangihe School," J. Educator's Reason., vol. 7, no. 1, pp. 85-93, 2019.

[55] RA Lismeida and RI Meilani, "Job Satisfaction and Teacher Performance: A Study of Certified Vocational Teachers in Indonesia," J. Educator. manaj. office, vol. 2, no. 1, pp. 57-65, 2017, doi:10.17509/jpm.v2i1.14612.

[56] WY Wu, CC Tsai, and CS Fu, "The Relationships Among Internal Marketing, Job Satisfaction, Relationship Marketing, Customer Orientation, And Organizational Performance: An Empirical Study Of TFT-LCD Companies In Taiwan,"Hum. Factors Ergon. Manuf. serv. eng., vol. 23, no. 5, pp. 436-449, 2012, doi: $10.1002 / \mathrm{hfm} .20329$.

[57] Y. Supiyanto, "The Effect of Compensation, Competence and Organizational Commitment on Satisfaction and Performance," J. Econ., vol. 11, no. 2, pp. 118-131, 2015 , doi:10.21831/economia.v11i2.8281.

[58] E. Ekawati, B. Semmaila, and Suriyanti, "Analysis of the Effect of Leadership Style, Job Satisfaction and Organizational Commitment to Improve Employee Performance at the Regional Secretariat of Kopta Parepare," Parad. J. Economics., vol. 2, no. 2, pp. 110, 2019, 